\title{
The Study on Influential Factors of the Congregation of Productive Service Sector
}

\author{
Meijuan Kang ${ }^{1} \&$ Zhiyu $\operatorname{Han}^{2}$ \\ ${ }^{1}$ Cust of Economics \& Management, Changchun University of Science and Technology, Changchun, China \\ ${ }^{2}$ Changchun Faway-Johnson Controls Publicity DP, Changchun, China \\ Correspondence: Meijuan Kang, Cust of Economics \& Management, Changchun University of Science and \\ Technology, Changchun 130025, China. E-mail: 99445126i@qq.com
}

Received: November 11, 2014

Accepted: November 17, 2014

Online Published: November 18, 2014

doi:10.5430/ijba.v5n6p88

URL: http://dx.doi.org/10.5430/ijba.v5n6p88

\begin{abstract}
With the rapid development of China's economy, the proportion of service industry in the national economy improved significantly, that the stimulating role of producer services in boosting the whole service industry development is even more apparent, there is an obvious phenomenon of spatial congregation. In this article, the author treat China's productive service sector's congregation as the research object, the tendency, formation mechanism and influencing factors of which has been analyzed. During this process, the author used basic theories of the new economic geography, on the basis of systematic summary and fully draw on the achievements of domestic and foreign scholars.
\end{abstract}

Keywords: productive service, sector congregation, influencing factors

The dominant factors, influencing the productive service sector and the transmission costs of product information, are IT and institutional factors, the level of knowledge spillover affects the cost of inter-regional capital formation, information transmission costs, the degree of knowledge spillover determines the agglomeration level of productive service sector, meanwhile urbanization and demographic changes, the scope of the market demand is also the main factor affecting the spatial positioning of the enterprise, this article will incorporate five aspects to illustrate the influential factors ranging from knowledge spillover, IT, urbanization to human capital, market demand and institutional factors.

\section{Knowledge Spillover Effect}

The knowledge spillover is the rebuilding of knowledge. Knowledge spillover process is characterized as chain effect, mimicking effect, the exchange effect, competition effect, driving effect, incentive effects. The new theory of economic growth and new trade theory have both stated that knowledge spillovers and economic growth are closely linked.

\subsection{The Connotation of the Knowledge Spillover}

Porter believes that "a cluster is not only a way of thinking viewpoint on economic development, but also as a means to trigger reform which has the advantage of flexibility. While the key theoretical basis for the cluster phenomenon is the existence of knowledge spillovers inside and outside the cluster." Productive service sector clusters are overlapped in regional and a large number of high-tech enterprises, research institutions, and there are a variety of $\mathrm{R}$ $\& \mathrm{D}$ talents dedicated in this cause, resulting in the formation of three comprehensive economic development system, incl. throughput, academic study, research and development.

The centralized congregation of regional planning enables the productive services sector cluster being featured with "extravert economies", the knowledge spillover effect allows the businesses with easy access to the core sources of knowledge are able to deliver innovative through puts in a short term than the other businesses relatively far from the core knowledge. The knowledge spillovers promote the development of industrial clusters, and vice versa the development of industrial clusters accelerates knowledge spillover application. Therefore, the knowledge spillover can be regarded as an important factor for the success of industrial clusters. 


\subsection{The Knowledge Spillovers Can Boost the Competitive Advantage of Industrial Clusters}

First of all, it is relatively at a lower cost for the enterprises within cluster to gain knowledge of production, with better efficiency.

Secondly, knowledge spillover can improve overall production efficiency of enterprise cluster, so that the proficiency and business professionalism of the production companies and producers can reach a higher level, business executives can utmost optimize the production means e.g. by adopting scientific and effective methods of production organization, or by hiring skilled technical staff.

The above-mentioned analysis can be summarized to the following conclusions, the greater the knowledge stock, and the better absorptive capacity of the knowledge spillover in one area, hence the more businesses can be attracted to this area.

\section{Urbanization and Human Capital}

\subsection{Urbanization and Productive Service Sector Congregation}

Urban Economics believes the city expansion will have positive impact on each industry. In view of the labor market, the expansion of the city provides space for the transfer of labor among industries, so as to effectively decrease search costs for labor, as well as to offer more jobs, better living conditions and richer cultural and recreational activities, resulting in more and more talents with different backgrounds continuously immigrating to the city.

\subsection{Human Capital}

The highly qualified talents are scarce resource for any industry, especially for the knowledge-intensive productive service sector. S.Illeris (1989) pointed out that the human resources are the "reservoir" as one of the three main factors to boost the spatial congregation of productive service sector. Wang Xiang (2011) evaluated the ratio of the number of urban personnel engaged in the scientific and technological activities in comparison with the state-wide average working people as a measuring indicator of human capital, taking the data from 2007 involving more than 232 county-level cities as examples to regress the comparison analysis between human capital and productive service congregation which turns out that the level of human capital level obviously has a positive effect on the development of productive service sector (Moulaert, Frank \& Gallouj, Camal, 1993).

The above analysis illustrates a linking map among the urbanization, talent congregation, productive service sector which are connected mutually restrained, interdependent and reinforcing, being shown in Figure 1. From the perspective of cause and effect, the mature urban functions enable individuals to realize their self-values by building a good social environment, and congregating the talents, so that enterprises have more qualified talents to select, the density and breadth of talent search are narrowed, the cost of talent search is lowered. In the meantime, the city resources are also congregated, the same as institutions, research centers, so that the productive service enterprises have better access to follow the trend and get market information, to make the rapid and responsive adaptation to the surrounding environment. Therefore, more and more enterprises are entering the cities. At the same time, talent and industry congregation are enhancing the urban competitiveness, vice versa, the better urban competitiveness further attract talent and industry congregation.

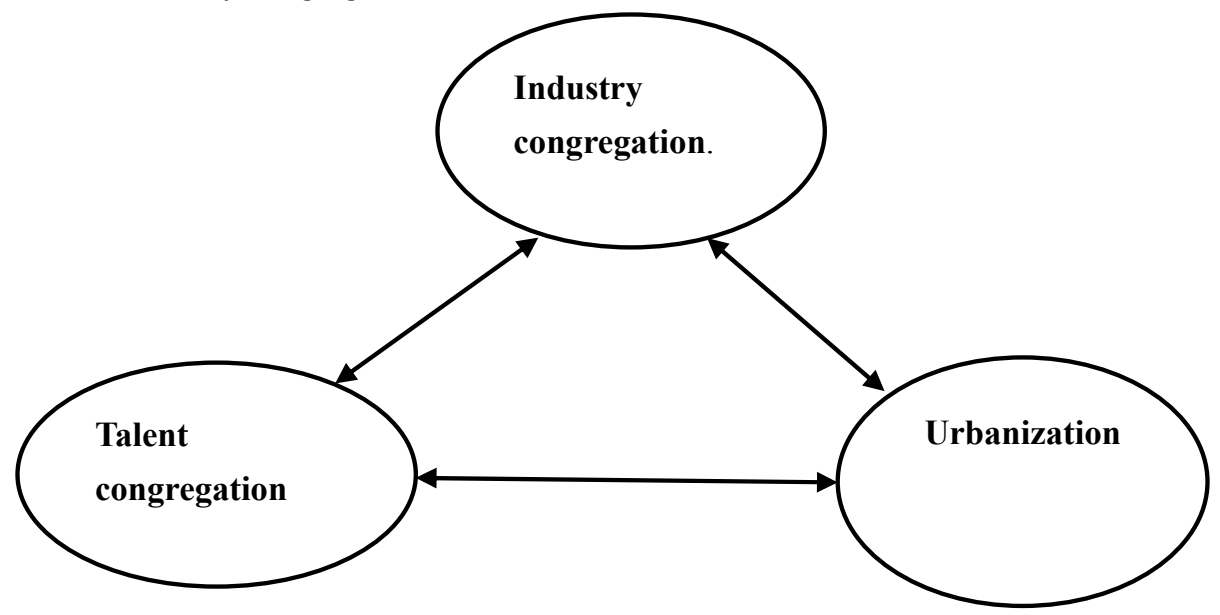

Figure 1 . The connection among urbanization, talent and industry congregation 


\section{IT Development}

An outstanding feature of the productive service sector is of its knowledge \& technology-intensiveness which depend significantly on the expertise to provide knowledge-based intermediate products or professional services to the clients from manufacturing and service sectors. The development of information technology will have a double impact on the spatial congregation of productive service sector, which viewpoint is derived from scholars as a common sense.

\subsection{The Distraction Force of IT to the Productive Service Sector}

We assume an economy being composed of two areas which marginal costs are A and B respectively, $F_{A}=a_{S}^{A} w(s), \quad F_{B}=a_{S}^{B} w(s)$, inside $a_{S}^{A}=1 /\left(K C_{A}\right), \quad C_{A}=r_{K}+\varepsilon\left(1-r_{K}\right) ; \quad a_{S}^{B}=1 /\left(K C_{B}\right) ; \quad C_{B}=\varepsilon r_{K}+\left(1-r_{K}\right) \quad \varepsilon \in[0,1], \quad \partial \varepsilon / \partial T>0$, IT development increases $\varepsilon$, so that the marginal costs of area A and B tend to be equal, the capital gains has less disparity between two areas, also the capital flow cross the areas is lowered. From the perspective of knowledge spillover, the development of information technology expands the knowledge spillover radius, the localization characteristics of knowledge spillover is hence less obvious, and the spatial congregation of the enterprises in the productive service sector is inhibited.

\subsection{The Centripetal Force of IT to the Productive Service Sector}

The development of information technology can reduce the cost of service and information transmission for enterprises in the productive service sector, $\partial \tau / \partial \mathrm{T}<0, \tau$ stands for information transmission costs, $\mathrm{T}$ stands for the IT level, to raise the free trade symbol $\varphi$ is beneficial to the congregation development of the enterprises in productive service sector, and development of information technology improves the knowledge stock capability, so as to achieve the separation of supply and demand with regard to time and space, as well as to extend the trade scope for service, so that the concentration of productive service sector is enhanced. Therefore, from the perspective of information transmission cost in a city or region, the more advanced the information technology is, meanwhile the more perfect the communication facilities are, hence, the better enterprise congregation can develop in the productive service sector.

\subsection{IT Impact on the Congregation of Productive Service Sector}

The spatial layout of the development of IT congregation has both the concentration force and the distraction force to the productive service sector, when the concentration force outweighs the distraction force, the development of information technology will facilitate the congregation development of production, otherwise it will inhibit. Scott $(1988,1993)$ believes that the development of information technology has shown a trend of distraction more and more imposed on the economic activities. The productive service sector, with requirement of face to face contact and highly "front (front office)" function, will still maintain the congregation trend; And the productive service sector with traditional "background (back office)" function will no longer require face to face contact, it can be located far from the downtown of the city, instead to choose the suburban region near a big city and cut the business cost (Krugman, P., 1999).

\section{Industrial Correlation}

In the consumer utility function, $U=A C_{M}^{1-\mu} C_{S}^{\mu}, \mu$ stands for consumer (the main customers of productive service sector refer to manufacturing and service enterprises) consumption in terms of production services, the demand curve facing the enterprises in the productive service sector is $q(s)_{i}=\mu E p(s)_{i}^{-\sigma} / \sum_{i=1}^{n} p(s)_{i}^{1-\sigma}$, assuming that the bigger $\mu$ is, the demand curve of enterprise will move to the right, the stronger the accumulative cause $\&$ effect relation of the need correlation of the region, the more obvious market proximity effect will be, it will hence attract more enterprises to congregate.

\subsection{Correlation between Productive Service Sector and Manufacturing Industry}

The chain of labor-intensive manufacturing industry is relatively shorter, whereas the production process of the technology-intensive manufacturing industry is more complex, "roundabout" is of a high level in production, which is, therefore, highly interactive with productive service sector. The different congregation forms in manufacturing industry varies from the demand for specific productive service sector, and the demand of productive service sector also varies based on each specific industry chain, the demand for productive service sector is less in the production 
phase, meanwhile there will be more demand for productive service sector in product design phase.

In general, the demand for labor-intensive manufacturing industry has relatively less demand for productive service sector, with minor interactivity; the capital-intensive manufacturing industry and technology-intensive manufacturing industry have relatively more demand for productive service sector, with better interactivity. The correlation can be illustrated below in Figure 2.

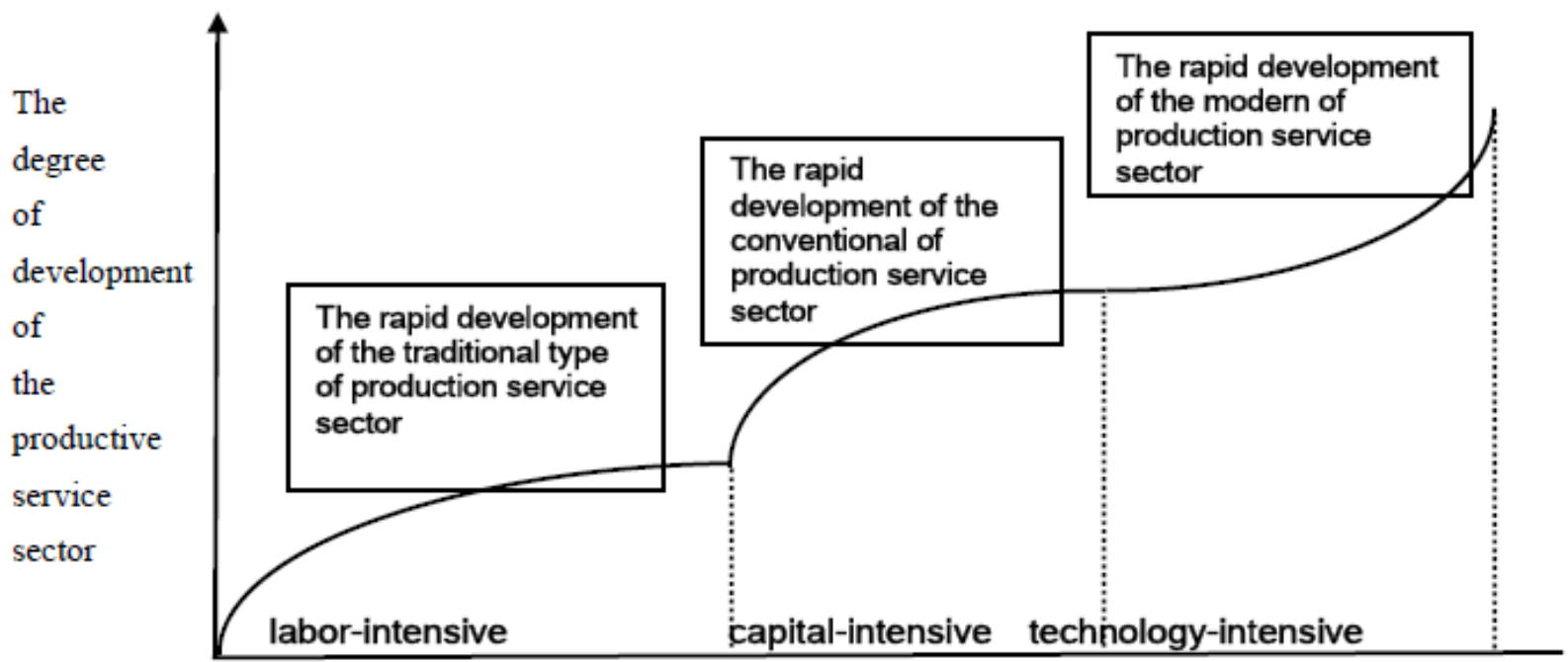

Figure 2. correlation between productive service sector and manufacturing industry

\subsection{The Self-correlation of Productive Service Sector}

The productive service sector is not only the intermediate input of manufacturing industry, but also the input of productive service sector. With the continuously increasing proportion of service sector in the national economy, the characteristics of productive service sector is more and more obvious to benefit mainly to the service sector. The study of Goe (1990), Beyers and Lindahl (1994) unveiled that the major department of western countries regarding with the productive service sector and product supply is the service department, rather than the manufacturing department.

According to the Chinese input-throughput table in 2007, this article has calculated the intermediate input rate of the productive service sector in each individual branch of service sector. In the service sector, the transportation and warehousing industry list out the top three branches: postal services (0.096117), wholesale and retail (0.089292), transportation and warehousing industry $(0.068213)$; the postal industry has three branches at highest rate of intermediate input: postal services (0.034025), public administration and social organizations (0.008696), education (0.003418); The top three branches at the highest rate of intermediate input industries in terms of information transmission, computer services and software industry are information transmission, computer services and the software industry (0.033929), the financial sector (0.025378), public administration and social organizations (0.022090); The three branches with highest intermediate inputs in the financial sector are financial sector (0.064194), transportation and warehousing industry (0.049833), leasing and business services (0.040017); leasing and business services have three branches at the highest rate of three intermediate input: wholesale and retail $(0.060466)$, the financial sector (0.044516), leasing and business services $(0.040614)$; The research and experiment development industries list out three highest rate branches: research and experiment development industry (0.020631), education (0.003166), wholesale and retail (0.001986); The three branches at highest rate of intermediate input are comprehensive technical services (0.048229), research and experiment development (0.011149), education (0.002863).

Based on the results of the calculation, the rate of intermediate input in the productive sector is higher than that in the overall services sector, in which the branches are associated to a large extent, there is a strong cumulative effect in the congregation of productive service sector. Therefore, the disparity of regional development in the service sector, especially the imbalanced internal structure of the service sector, will result in the inequality of spatial congregation 
in the productive service sector.

\section{Institutional Environment Factors}

Industry congregation is generally in close relation with the institutional factors, such as the open economic policies are favorable to the industrial division, while improving the professionalism of the region, as well as facilitating industrial congregation. On the other hand, the conservative government actions can easily impede the free flow of production means, thus impairing industrial congregation. Because of the way of statistics for products in manufacturing industry in an easy manner, in particular, the labor productivity in manufacturing industry is higher than that in the service sector. On a basis of GDP indicator in the current performance evaluation system, many local governments focus more on promoting the development of manufacturing industries, which tend to attract foreign investment by providing favorable tax tariff. Alternatively, the governments can adopt supportive policies to support partial industrial business in a comparative advantageous industry to stimulate local economic development, and in a certain sense to promote the congregation of manufacturing industry.

The emergence and development of productive service sector is ultimately derived from professionalized economy and in-depth labor division, which is the fundamental condition for the emergence of productive service sector. The deepening labor division means the transformation from socio-economic model of self-sufficiency to market transactions, the deepening labor division is, the more frequent the transactions among market entities are, thus the greater the total transaction costs are; However, the high transaction costs will hamper the further development of the labor division, there is a dilemma between professionalized economy and transaction costs. Therefore, reducing the transaction costs in institutional plan plays a decisive role in promoting the labor division, and raising the professional level.

\subsection{Legal Environment and the Congregation of Productive Service Industry}

Wang Dehua (2007) takes 114 countries as an example, which analyzes the relationship among the size of governments, the rule of law and the level of service development, research results unveil that the quality of upholding the contract system of rule of law in a country can be also in positive correlation with the proportion of services sector, and in an obviously negative correlation with the government size and the proportion of the service industry.

\subsection{Government Size and Productive Service Congregation}

Referring to the relationship between government size and economic growth, there is a completely different interpretation with the argument that the government size is hindering economic growth or promoting economic growth. A group of cross-sectional data from 98 countries collected by Ram (1986), Barro (1991), Gwartney (1998) etc., involving the 23 OECD member countries based on the panel data from 1960 to 1996, proved that there is a negative correlation between the government size and economic growth.

The regression analysis made by Huang Lei (2008) 1982-2006 with the data from 28 provinces and cities, in which the proportion of government consumption out of GDP stands for government size, and the proportion of added value from service sector out of regional GDP stands for the level of development of the service sector, unveiled that there is a positive correlation between them, and the government size in the high-income areas have bigger positive impact on the service sector than that in the low-income areas. The regression analysis was conducted to study their correlation in different time period which turned out to be positively correlated from 1982 to 2002, while it was negatively correlated from 2002 to 2006, and the negative correlation coefficient from 2004 to 2006 between the two was bigger than that from 2003 to 2005. The illustrates the relationship between the government size and service sector development depends on the perfection degree of the market economy system, under conditions of imperfect market system, the larger government size is favorable to the development of the service sector; In the case of relatively perfect market economy system, the larger government size will hinder the development of the service sector (Krugman, P., 1999).

\subsection{Government Regulation and Congregation of Productive Service Industry}

The study conducted by Sherry (2009) illustrates that the more loose the economic liberalization is, the higher the convenience of enterprises finance is, thus there will be obviously more congregation attracted to capital-intensive and technology-intensive industry. At present, the productive service sector in terms of finance and telecommunication etc. are imposed of strict entry regulation. By the end of 2010, state-wide foreign-invested enterprises had totals of registered foreign capital \$ 1.259 trillion, in which manufacturing industry accounted for $51 \%$, real estate was $14.7 \%$, while the percentage of transportation, storage and postal industry was $2.29 \%$, information transmission, computer services and software industry accounted for $4.91 \%$, the financial sector was 
$2.18 \%$, leasing and business service industry was $7.37 \%$, scientific research, technical services and geological prospecting accounted for $3.81 \%$. These data unveils that there are areas in productive service sector under strict foreign investment control.

In summary, the knowledge stock, the congregation degree of the service sector, urbanization and human capital all play active roles in the congregation development of productive service sector, the government size and the development level of productive service sector demonstrate a negative correlation, the information level has less impact on the congregation of productive service sector, which shows a negative correlation in the east of China, whereas a positive correlation in the mid-west China.

\section{References}

Daniels, P. (1985). Services Industries: A geographical Appraisal. London: Methuen.

Howells, J., \& Green, A. (1985). Location,technology,and industrial orga-nization in UK services. Progress in Planning, (02), 16-34.

Illeris, S. (1989). Producer services:The key sector for future economic development. Entrepreneurship and Regional Development, (03), 267-274.

Krugman, P. (1999). Geography and Trade. MIT Press.

Moulaert, Frank, \& Gallouj, Camal. (1993). The locational geography of advanced producer service firms: The limits of economies of agglomeration. The Service Industries Journal, 13(4). 